\title{
GPR101 Gene
}

National Cancer Institute

\section{Source}

National Cancer Institute. GPR101 Gene. NCI Thesaurus. Code C113540.

This gene may play a role in receptor signaling. 